\title{
Evaluasi Potensi Likuifaksi di Wilayah Cekungan Bandung Berdasarkan Metode Analisis Multi-Sensor Gelombang Permukaan
}

\author{
Nur Amalia Dewi ${ }^{1}$, Adrin Tohari ${ }^{2}$, Imamal Muttaqien ${ }^{1}$ \\ ${ }^{1}$ Jurusan Fisika, Fakultas Sains dan Teknologi, Universitas Islam Negeri Sunan Gunung Djati Bandung, \\ Jl. A.H. Nasution, Cibiru Bandung 40614 \\ ${ }^{2}$ Pusat Penelitian Geoteknologi, LIPI, Jl. Sangkuriang, Cisitu, Bandung 40135
}

\begin{abstract}
ABSTRAK Secara geologi, wilayah Cekungan Bandung tersusun oleh endapan danau Bandung purba yang terdiri atas lapisan lempung dengan sisipan lapisan pasir sehingga rentan terhadap likuifaksi akibat gempa bumi. Metode analisis multi-sensor gelombang permukaan (MASW) adalah salah satu metode geofisika yang menghasilkan model satu dimensi kecepatan gelombang geser $(V s)$ terhadap kedalaman. Makalah ini menyajikan hasil analisis potensi likuifaksi menggunakan data profil $V s$ di 5 lokasi yang tersebar di wilayah Cekungan Bandung. Data $V s$ diperoleh dengan menggunakan 24 geophone yang tersebar dengan spasi 4 meter di setiap lokasi penelitian. Hasil analisis data menggunakan metode $M A S W$ menghasilkan profil $V s$ dan $V s 30$ di setiap lokasi yang menunjukkan bahwa lapisan tanah di wilayah Cekungan Bandung dapat diklasifikasi dalam kelas situs E dan D. Sedangkan berdasarkan hasil analisis potensi likuifaksi menggunakan profil $V s$, dengan mempertimbangkan percepatan tanah puncak yang dihasilkan oleh Sesar Lembang $\left(M_{w} 6,5\right)$, mengindikasikan bahwa lapisan pasir di dalam endapan danau purba mempunyai potensi likuifaksi pada kedalaman dan ketebalan yang bervariasi. Lapisan pasir dengan nilai $V s<175$ $\mathrm{m} /$ detik yang menyebabkan potensi likuifaksi di daerah Bojongemas lebih tinggi dibandingkan dengan daerah lainnya. Hasil penelitian ini menunjukkan kesesuaian dengan hasil analisis
\end{abstract}

Naskah masuk : 1 Oktober 2020

Naskah direvisi : 5 Desember 2020

Naskah diterima : 16 Desember 2020

*Penulis korespondensi.

Email: adrin.tohari@gmail.com likuifaksi berdasarkan metode uji penetrasi standar dari hasil penelitian terdahulu.

Kata kunci: gelombang permukaan, kelas situs, kecepatan gelombang geser, likuifaksi, $M A S W$

ABSTRACT - The Evaluation of Liquefaction
Potential in Bandung Basin Area Based on
Multi-Channel Analysis of Surface Wave. The Bandung Basin region is composed of ancient Bandung lake sediment deposits consisting of thick clay layers intercalated with sand layers, which is vulnerable to liquefaction due to earthquakes. The Multi-channel Analysis of Surface Wave (MASW) analysis method is a geophysical method that produces a onedimensional model of shear wave velocity (Vs) against depth. This paper presents the results of an analysis of the potential for liquefaction using $V$ s profile data at 5 locations spread across the Bandung Basin. using 24 geophones with 4-m spacing. The results of data analysis using the MASW method produce Vs and Vs30 profiles at each location which indicate that the soil layers in the Bandung Basin area can be classified into $E$ and $D$ site classes. Meanwhile, based on the results of the analysis of potential liquefaction using the Vs profile, taking into account the peak soil acceleration produced by the Lembang Fault (Mw 6.5), indicates that the sand layer in ancient lake sediment deposits has the potential for liquefaction at varying depths and thicknesses. Sand layer with a value of Vs $<175 \mathrm{~m} / \mathrm{sec}$ which causes the potential for liquefaction in the Bojongemas area is higher than in the other areas. The results of this study confirm liquefaction analysis based on the standard penetration test method from the previous study. 
Keywords: surface wave, site class, shear wave velocity, liquefaction, MASW

\section{PENDAHULUAN}

Daerah Cekungan Bandung terbentuk dari endapan sedimen danau purba dengan jenis tanah lempung, lanau, dan pasir dengan tingkat kepadatan tanah yang lepas, hal ini sangat rentan terhadap getaran dari gempa bumi (Handayani et al., 2009). Di daerah Cekungan Bandung terdapat sumber gempa bumi yaitu Sesar Lembang (Daryono et al., 2019). Sesar Lembang terletak sekitar $10 \mathrm{~km}$ di sebelah Utara Kota Bandung. Sesar Lembang merupakan sesar dengan jenis strike slip atau sesar mendatar, Sesar Lembang telah lama aktif dengan laju pergerakan 1,95 - 3,45 mm per tahun dengan panjang $29 \mathrm{~km}$, Sesar Lembang dapat menghasilkan gempa bumi Mw 6,5-7,0 dengan waktu pengulangan 170-670 tahun (Daryono et al., 2019). Gempa bumi dengan intensitas gempa 3,3 SR pernah terjadi pada Agustus 2011 di daerah Cisarua, Lembang, Kabupaten Bandung Barat akibat adanya pergerakan Sesar Lembang (Sulaeman dan Hidayati, 2011).

Salah satu dampak dari gempa bumi adalah terjadinya likuifaksi. Beberapa kejadian likuifaksi pernah terjadi di beberapa wilayah di Indonesia diantaranya likuifaksi yang terjadi akibat gempa bumi di Aceh pada tahun 2004 (Mw 9,1), di wilayah Nias pada tahun 2005 (Mw 8,7), di wilayah Bantul pada tahun 2006 (Mw 6,3), di wilayah Bengkulu pada tahun 2007 (Mw 8,4), di kota Padang pada tahun 2009 (Mw 7,6) dan di wilayah Palu pada tahun 2018 (Mw 7,4) yang menyebabkan korban jiwa dan kerugian ekonomi yang besar (Ambarwati et al., 2020).

Likuifaksi terjadi pada tanah pasir lepas yang jenuh air akibat kenaikan tekanan air pori saat terjadinya gempa bumi yang menyebabkan tekanan efektif lapisan pasir tersebut akan berkurang seiring waktu (Towhata, 2008). Kerentanan lapisan pasir terhadap likuifaksi akan menurun dengan bertambahnya kedalaman muka air tanah (Youd et al., 1979).

Berdasarkan kondisi geologi, daerah Cekungan Bandung berpotensi mengalami likuifaksi jika terjadi gempabumi besar (Febriana et al., 2020). Faktor kedalaman muka air tanah yang dangkal $(<15 \mathrm{~m})$ juga akan menyebabkan kerentanan terhadap likuifaksi daerah Cekungan Bandung (Febriana et al., 2020).
Terdapat tiga metode investigasi geoteknik dan geofisika in-situ yang digunakan untuk menganalisis potensi likuifaksi, yaitu metode uji penetrasi konus $(C P T)$, uji penetrasi standard $(S P T)$, kecepatan gelombang geser (Vs) (Idriss and Boulanger, 2008). Selain itu, metode geolistrik juga digunakan untuk mempelajari lapisan pasir yang terlikuifaksi (Giocoli et al., 2014). Febriana et al. (2020) melakukan analisis potensi likuifaksi di daerah Bojongemas, Rancakasumba, Rancaekek Kencana dan Sumbersari dengan metode SPT dan Ambarwati et al. (2020) menghasilkan kajian potensi likuifaksi di wilayah Cekungan Bandung dengan menggunakan metode uji penetrasi konus (CPT).

Metode Multi-channel Analysis of Surface Wave $(M A S W)$ menghasilkan data yang berada di permukaan dengan menganalisis gelombang Rayleigh yaitu dengan memanfaatkan sifat dispersi ground roll menggunakan data kecepatan gelombang geser (Shearer, 2009). Dari profil data $V s$ yang dihasilkan, kita dapat menentukan kelas tapak dengan rata-rata $V s$ di kedalaman $30 \mathrm{~m}$ (Vs30), ketebalan lapisan tanah dan lapisan batuan dasar untuk analisis potensi likuifaksi (Villaverde, 2009). Data $V s$ juga sering digunakan untuk pengklasifikasian batuan akibat dari adanya gempa bumi sehingga sering digunakan untuk menguji bangunan yang tahan gempa dan mitigasi bencana (Sucuoğlu dan Akkar, 2014).

Ada beberapa kelebihan untuk analisis potensi likuifaksi dengan menggunakan metode $V s$ yaitu dalam proses pengambilan data di lapangan dapat dilakukan pada tanah yang sulit diambil samplenya, seperti tanah berkerikil sehingga lebih mudah dibandingkan dengan metode pengujian lapangan lainnya dan data $V s$ diperlukan dalam respons struktur tanah serta pengklasifikasian tanah atau kelas tapak. Adapun kekurangan dalam metode ini yaitu diperlukan beberapa data sekunder untuk melengkapi data sehingga dapat menganalisis tanah yang berpotensi likuifaksi, yaitu data jenis tanah, kepadatan tanah serta kedalaman muka air tanah (Andrus dan Stokoe, 2000).

Makalah ini menyajikan hasil analisis potensi likuifaksi di daerah Cekungan Bandung dengan menggunakan metode $M A S W$ yaitu berdasarkan data (a) profil $V s$ lapisan tanah, (b) data $V s 30$ dan klasifikasi tapak, dan (c) data kedalaman lapisan 
Tabel 1. Lokasi pengambilan data di daerah Cekungan Bandung

\begin{tabular}{clccc}
\hline \multirow{2}{*}{$\begin{array}{c}\text { Kode } \\
\text { lokasi }\end{array}$} & \multicolumn{1}{c}{ Lokasi } & \multicolumn{2}{c}{ Koordinat } & \multirow{2}{*}{$\begin{array}{c}\text { Kedalaman muka } \\
\text { airtanah (m) }\end{array}$} \\
\cline { 3 - 4 } & & ${ }^{\circ} \mathbf{L S}$ & ${ }^{\circ} \mathbf{B T}$ & 7,0 \\
\hline S1 & Bojongemas, Kec. Solokan Jeruk & -6.997 & 107.733 & 15,0 \\
S2 & Rancaekek Kencana, Kec. Rancaekek & -6.974 & 107.758 & 3,0 \\
S3 & Rancakasumba, Kec. Solokan Jeruk & -7.009 & 107.725 & 3,0 \\
S4 & Rancakasumba, Kec. Solokan Jeruk & -7.027 & 107.743 & 3,0 \\
S5 & Sumbersari, Kec. Ciparay & -6.996 & 107.693 & \\
\hline
\end{tabular}
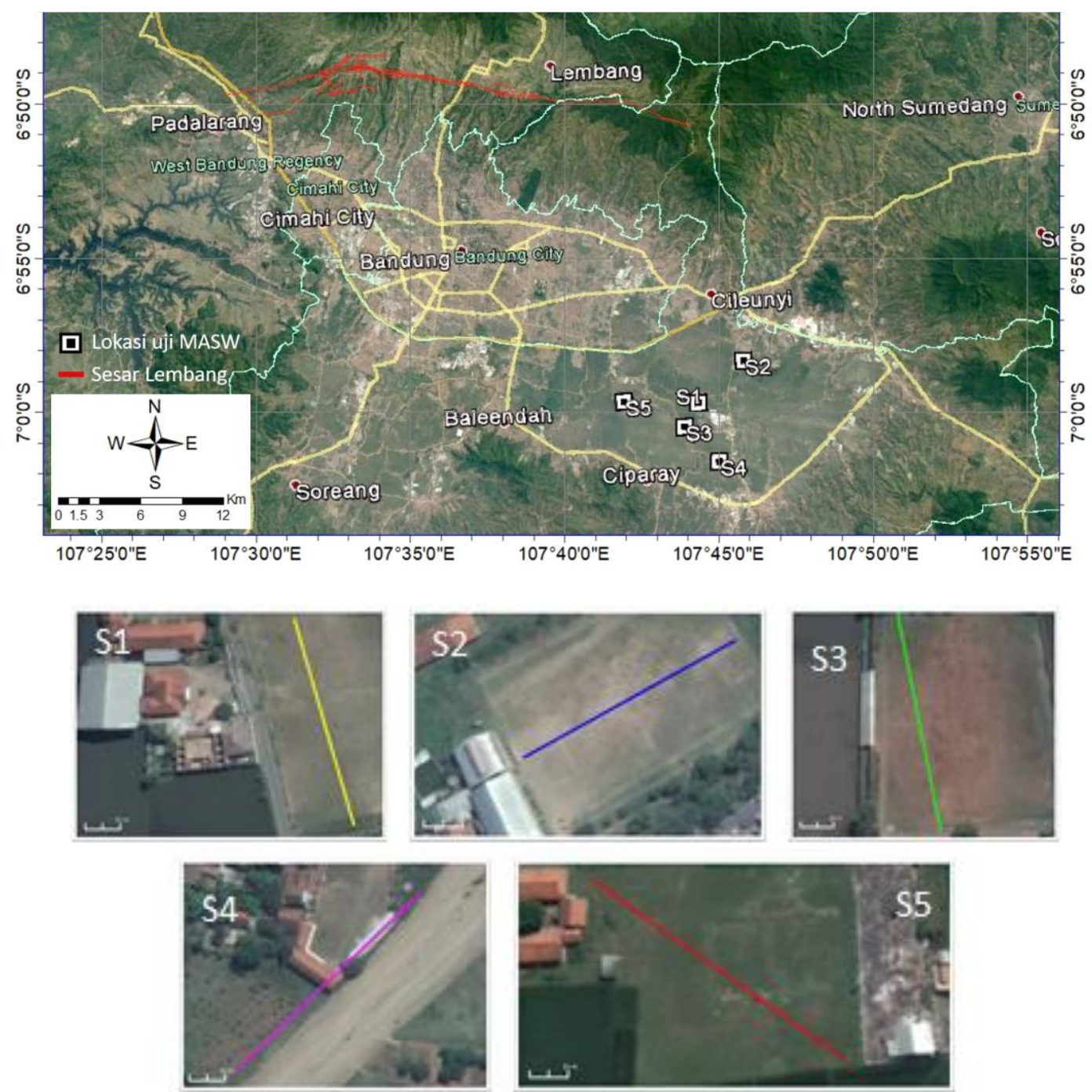

Gambar 1. Peta lokasi pengambilan data MASW di wilayah Cekungan Bandung: S1 (Bojongemas), S2 (Rancaekek Kencana), S3 (Rancakasumba), S4 (Rancakasumba) dan S5 (Sumbersari). 
tanah yang berpotensi likuifaksi di beberapa wilayah di Cekungan Bandung.

\section{TATANAN GEOLOGI CEKUNGAN BANDUNG}

Wilayah Cekungan Bandung mencakup tiga unit administrasi, yang terdiri dari Kabupaten Bandung, Kota Bandung, dan sebagian dari Kabupaten Sumedang. Pada bagian tengah, wilayah Cekungan Bandung dikelilingi oleh dataran tinggi vulkanik berumur Akhir Tersier dan Kuarter yang memiliki ketinggian sekitar $665 \mathrm{~m}$ hingga $2400 \mathrm{~m}$ (Dam et al., 1996).

Secara geologi, lapisan batuan penyusun Cekungan Bandung terdiri dari 4 formasi batuan berumur Tersier hingga Holosen (Sudjatmiko, 2003; Koesoemadinata dan Hartono, 1981). Formasi Kosambi adalah formasi batuan termuda yang dijumpai di wilayah Cekungan Bandung bagian tengah. Formasi Kosambi ini diusulkan oleh Koesoemadinata dan Hartono (1981) untuk menggantikan nama Endapan Danau yang digunakan oleh Silitonga (1973). Berdasarkan litologinya, formasi ini terdiri atas endapan lempung, lanau, dan pasir yang belum kompak dengan umur Holosen.

Cekungan air tanah di wilayah Cekungan Bandung memiliki luas sekitar $1.730 \mathrm{~km} 2$ dan terdiri dari empat sistem akuifer yang mengandung air tanah potensial yaitu Formasi Rajamandala, Formasi Cibeureum, Formasi Cikapundung dan Formasi Kosambi. Berdasarkan letak dan kondisinya, Harnandi et al. (2000) membagi 4 sistem akuifer ini menjadi tiga kelompok akuifer yaitu dari akuifer dangkal pada kedalaman 0-40 $\mathrm{m}$, akuifer tengah pada kedalaman 40-150 $\mathrm{m}$ dan akuifer dalam yang teletak pada kedalaman $>150 \mathrm{~m}$. Berdasarkan data kedudukan muka air tanah dan peta sebaran muka air tanah, Hutasoit (2009) juga berpendapat bahwa terdapat beberapa daerah di wilayah Cekungan Bandung yang memiliki kedudukan muka air tanah yang dangkal $(<10 \mathrm{~m})$.

\section{METODE}

\section{Penentuan kecepatan gelombang geser $(V s)$}

Metode penelitian yang digunakan adalah metode $M A S W$ untuk identifikasi kondisi bawah permukaan bumi dengan menganalisis gelombang permukaan (Hayashi, 2003). Penelitian dilakukan di daerah Rancaekek Kencana, Bojongemas, Rancakasumba dan Sumbersari yang berada di wilayah Cekungan Bandung dengan data kedalaman muka air tanah yang bersumber dari data pemboran (Gambar 1 dan Tabel 1) sesuai dengan hasil penelitian Febriana et al. (2020). Penelitian ini dilakukan dengan menggunakan alat Geometrics ES-3000 yang merupakan set alat seismik refraksi.

Pada tahap akuisisi data dalam $M A S W$ dengan menggunakan penerima gelombang (receiver) 24 geophone komponen vertikal dengan frekuensi 4.5 $\mathrm{Hz}$ dan sumber yang digunakan berupa palu seberat $5 \mathrm{~kg}$ dengan 7 sumber getaran dan interval jarak di antara geophone $4 \mathrm{~m}$ sehingga total jarak pada lintasan adalah 96 meter.

Nilai kecepatan gelombang geser $(V s)$ didapatkan dengan tahap data processing menggunakan software SeisImager, yaitu mengubah data rekaman yang ditangkap oleh geophone yang berada dalam domain waktu menjadi domain frekuensi menggunakan transformasi Fourier hasilnya akan diubah menjadi kecepatan fase terhadap frekuensi (Olafsdottir, 2014). Kemudian proses picking kurva dispersi dengan pemilihan mode fundamental yaitu dengan memilih amplitudo tertinggi (Lu dan Wilson, 2017). Proses picking kurva dispersi ini menggunakan software SeisImager pada bagian Surface Wave Analysis Wizard. Tahap akhir dari processing ini adalah proses inversi untuk menghasilkan model 1D kecepatan gelombang geser (Vs) terhadap kedalaman (Grandis, 2009), dengan melakukan iterasi sehingga sehingga menghasilkan model $V s$ 1D yang lebih baik dibandingkan dengan model awal. Data kecepatan gelombang geser semakin besar beriringan dengan kedalamannya. Model 1D dapat dianalisis lebih lanjut dengan mempertimbangkan nilai Root Mean Square Error (RMSE) yang dihasilkan. Jika persentase kesalahan pada model 1D bernilai kecil maka akan semakin baik model 1D yang dihasilkan. Model 1D yang dihasilkan di setiap lokasi penelitian bervariasi dan dapat menentukan kelas tapak berdasarkan nilai rata-rata kecepatan gelombang geser hasil inversi hingga kedalaman 30 meter (Vs30) (Pegah and Liu, 2016). Nilai Vs30 dihitung dengan menggunakan rumus sebagai berikut:

$$
V s 30=\frac{\sum_{i=1}^{m} d_{i}}{\sum_{i=1}^{m} \frac{d_{i}}{V s_{i}}}
$$


di mana $i$ adalah indeks lapisan, $m$ adalah jumlah lapisan hingga kedalaman 30 meter, $d_{i}$ adalah ketebalan lapisan ke i (m), $V s_{i}$ adalah Kecepatan gelombang geser lapisan ke i (m/detik).

\section{Penentuan percepatan tanah puncak (PGA)}

Penentuan nilai percepatan tanah puncak ( $P G A)$ di batuan dasar dengan menggunakan pendekatan empiris atau fungsi atenuasi. Fungsi atenuasi merupakan fungsi yang menggambarkan hubungan antara intensitas tanah, magnitudo $(M)$ dan jarak $(R)$ dari lokasi sumber di daerah sumber gempa. Beberapa studi terdahulu telah menghasilkan fungsi atenuasi untuk sumber gempa sesar dangkal, diantaranya Boore et al. (1997). Meskipun sudah banyak pula fungsi atenuasi terbaru untuk sumber gempa dangkal, seperti Boore dan Atkinson (2008), Campbell dan Bozorgnia (2008), dan Chiou dan Youngs (2008), fungsi atenuasi Boore dan Atkinson (1997) masih digunakan oleh beberapa peneliti untuk mengestimasi nilai $P G A$ yang dihasilkan dari zona sesar dangkal (Sa'adah et al., 2015; Erken et al., 2018; Darvasi dan Agnon, 2019). Untuk penelitian ini, nilai $P G A$ di setiap lokasi pengukuran $V s$ ditentukan dengan menggunakan fungsi atenuasi Boore et al., 1997, sebagai berikut:

$$
\begin{aligned}
\log (Y)= & b_{1}+b_{2}(M-6)+b_{3}(M-6)^{2}+ \\
& b_{5} \log (r)+b_{v}\left(\log V_{s} 30-\log V_{A}\right)
\end{aligned}
$$

di mana

$$
r=\sqrt{d^{2}+h^{2}}
$$

di mana $Y$ adalah percepatan tanah horizontal (g), $M$ adalah magnitudo gempa, $r$ adalah jarak hiposenter $(\mathrm{km}), d$ adalah jarak episenter $(\mathrm{km}), h$ adalah jarak kedalaman sumber gempa (km), Vs30 adalah kecepatan gelombang geser ( $\mathrm{m} /$ detik), $b_{1}=$ $-0,313, b_{2}=0,527, b_{3}=0, b_{5}=-0,778, b_{\mathrm{v}}=-0,371$, $V_{A}=1396$.

\section{Penentuan potensi likuifaksi}

Untuk menentukan tanah yang berpotensi likuifaksi dapat dilakukan dengan menghitung faktor keamanan terhadap likuifaksi $\left(F K_{l i q}\right)$. FK ini merupakan perbandingan rasio tegangan siklik atau Cyclic Stress Ratio (CSR) (Seed and Idriss, 1971) dengan rasio hambatan siklik atau Cyclic Resistance Ratio (CRR). Perumusan ini didasarkan pada data observasi dari beberapa lokasi likuifaksi dengan 26 gempa bumi dan pengukuran kecepatan gelombang geser $(V s)$ lebih dari 70 situs (Andrus dan Stokoe, 2000). Perhitungan CSR dengan menggunakan formulasi Seed and Idriss (1971) sebagai berikut:

$$
C S R=0,65 \frac{a_{\max }}{g} \frac{\sigma_{v}}{\sigma_{v}^{\prime}} r_{d}
$$

di mana $C S R$ adalah rasio tegangan siklik, $a_{\max }$ adalah percepatan puncak di permukaan tanah (g), $g$ adalah percepatan gravitasi $(\mathrm{g}), \sigma_{v}$ adalah tegangan vertikal total pada kedalaman $z\left(\mathrm{kN} / \mathrm{m}^{2}\right)$, $\sigma_{v}{ }^{\prime}$ adalah tegangan vertikal efektif pada kedalaman $z\left(\mathrm{kN} / \mathrm{m}^{2}\right)$ dan $r_{d}$ adalah faktor reduksi tegangan geser. Untuk penelitian ini, data tegangan vertikal total $\left(\sigma_{v}\right)$ dan tegangan vertikal efektif $\left(\sigma_{v}{ }^{\prime}\right)$ untuk setiap jenis lapisan tanah diperoleh dari hasil uji $C P T u$ dan pemboran teknik di setiap lokasi penelitian (Febriana et al., 2020; Ambarwati et al., 2020).

Sementara itu, nilai rasio hambatan siklik atau Cyclic Resistance Ratio yang berlaku untuk gempabumi dengan magnitudo 7,5 $\left(C R R_{7,5}\right)$ berdasarkan data kecepatan gelombang geser $(V s)$ dihitung dengan menggunakan rumus Andrus dan Stokoe (1997; 2000) sebagai berikut:

$C R R_{7,5}=0,022\left(\frac{V_{s 1}}{100}\right)^{2}+2,8\left(\frac{1}{V_{s 1}^{*}-V_{s 1}}-\frac{1}{V_{s 1}^{*}}\right)(5)$

di mana $C R R_{7,5}$ adalah rasio hambatan siklik untuk magnitudo gempa, $\mathrm{Mw}=7,5, V_{s l}$ adalah kecepatan gelombang geser dengan koreksi tegangan (m/detik), $V_{s I}{ }^{*}$ adalah kecepatan gelombang geser ( $\mathrm{m} /$ detik) yang dipengaruhi persentase butiran halus. Dalam studi ini, persentasi butiran halus diperoleh dari hasil penelitian oleh Febriana et al. (2020).

Untuk menentukan nilai dari kecepatan gelombang geser dengan koreksi tegangan menggunakan formulasi sebagai berikut (Sykora, 1987; Robertson et al., 1992):

$$
V_{s 1}=V_{S} \cdot C_{v}=V_{S}\left(\frac{P_{a}}{\sigma_{v}^{\prime}}\right)^{0,25}
$$

di mana $V_{s 1}$ adalah kecepatan gelombang geser (m/detik), $\quad C_{v}$ merupakan faktor koreksi pengukuran $V_{s}$ untuk tekanan overburden, $P_{a}$ merupakan referensi tegangan yaitu $100 \mathrm{kPa}$ atau tekanan atmosfer $1 \mathrm{~atm}, \sigma_{v}$ merupakan tegangan 
efektif. Sedangkan untuk menentukan nilai $V_{s I}{ }^{*}$ yaitu dengan menggunakan hubungan persentase butiran halus $(\% F C)$ sebagai berikut:

○ untuk pasir dengan $F C \leq 5 \%$

$$
V_{s 1}^{*}=215 \mathrm{~m} / \mathrm{detik}
$$

○ untuk pasir dengan $5 \%<F C<35 \%$ $V_{S 1}^{*}=215-0,5(F C-5) \mathrm{m} / \mathrm{detik}$

○ untuk pasir dengan $F C \geq 35 \%$ $V_{s 1}^{*}=200 \mathrm{~m} /$ detik

Untuk menentukan nilai $C R R$ dengan magnitudo selain 7,5, maka nilai rasio hambatan siklik dapat dirumuskan dengan persamaan berikut ini:

$$
C R R_{M}=C R R_{7,5} \times M S F
$$

di mana MSF adalah Magnitude Scaling Factor atau faktor kelipatan besaran gempa bumi.

Hasil perhitungan dari $C S R$ dan $C R R_{M}$ digunakan untuk menentukan faktor keamanan $\left(F K_{\text {liq }}\right)$ yang merupakan faktor untuk penentuan potensi likuifaksi dengan menggunakan formulasi sebagai berikut:

$$
F K_{\text {liq }}=C R R_{M} / C S R
$$

Untuk lapisan yang berpotensi likuifaksi, nilai $C R R_{M}$ akan lebih kecil dibanding nilai $C S R$. Dengan demikian, penentuan potensi likuifaksi dapat dilihat pada nilai $F K_{\text {liq }}$, jika $F K_{\text {liq }} \leq 1,0$ maka likuifaksi akan terjadi, dan jika $F K_{l i q}>1,0$ maka likuifaksi tidak akan terjadi (Andrus and Stokoe, 2000).

\section{HASIL DAN PEMBAHASAN}

\section{Kurva dispersi dan model $V s$}

Kurva dispersi dan model 1D dari proses inversi menggunakan software SeisImager dapat dilihat pada Gambar 2 hingga Gambar 7.

Gambar 2 menyajikan kurva dispersi untuk lokasi S1 di Desa Bojongemas dengan nilai frekuensi berkisar antara $4 \mathrm{~Hz}$ hingga $28 \mathrm{~Hz}$ dan kecepatan fase data observasi berkisar antara 103,05 m/detik hingga $157,95 \mathrm{~m} /$ detik dan data prediksi dengan kecepatan fase berkisar antara 102,34 m/detik hingga $153,74 \mathrm{~m} /$ detik. Perbedaan dari data observasi dan prediksi pada kurva dispersi menghasilkan nilai $R M S E$ sebesar $2,18 \%$, dengan iterasi sebanyak 12 kali. Gambar 2 juga menunjukkan kenaikan nilai $V s$ hasil inversi terhadap kedalaman, mulai dari 106,05 $\mathrm{m} /$ detik di permukaan tanah hingga mencapai $178,91 \mathrm{~m} /$ detik di kedalaman $30 \mathrm{~m}$.

Gambar 3 memperlihatkan kurva dispersi untuk lokasi S2 di Kelurahan Rancaekek Kencana, dengan nilai frekuensi berkisar antara $4 \mathrm{~Hz}$ hingga $28 \mathrm{~Hz}$ dan kecepatan fase berdasarkan data observasi berkisar antara 143,4 m/detik hingga $199,2 \mathrm{~m} /$ detik dan berdasarkan data prediksi berkisar antara 142,86 m/detik hingga 198,08 m/detik. Kurva dispersi mempunyai nilai $R M S E$ sebesar 0,99\% dengan iterasi sebanyak 20 kali. Gambar 3 juga menyajikan merupakan model 1D kecepatan gelombang geser (Vs) terhadap kedalaman hasil dari proses inversi dari model awal Vs. Gambar 3 ini menunjukkan kenaikan Vs terhadap kedalaman, dimulai dari nilai 149,02 $\mathrm{m} /$ detik hingga mencapai nilai $227,21 \mathrm{~m} /$ detik pada kedalaman $30 \mathrm{~m}$. Dengan demikian, nilai $V s$ di lokasi S2 lebih tinggi dari pada nilai $V s$ di lokasi S1.

Kurva dispersi untuk lokasi S3 di Desa Rancakasumba (Gambar 4), menunjukkan nilai frekuensi berkisar antara $4 \mathrm{~Hz}$ hingga $28 \mathrm{~Hz}$ dan kecepatan fase berdasarkan data observasi berkisar 111,15 m/detik hingga 156,15 m/detik dan berdasarkan data berkisar antara 111,16 $\mathrm{m} /$ detik hingga $155,87 \mathrm{~m} /$ detik. Kurva dispersi mempunyai nilai $R M S E$ sebesar $0,76 \%$ dengan iterasi sebanyak 20 kali. Pada Gambar 4 juga dapat dilihat model 1D kecepatan gelombang geser $(V s)$ terhadap kedalaman hasil dari proses inversi dari model awal $V s$. Peningkatan $V s$ terhadap kedalaman dapat terlihat jelas (Gambar 4), dimulai dari nilai 112,26 m/detik hingga mencapai nilai $175,81 \mathrm{~m} /$ detik pada kedalaman $30 \mathrm{~m}$. Nilai $V s$ ini lebih rendah jika dibandingkan dengan nilai $V s$ di lokasi S2, tetapi hampir sama dengan nilai $V s$ di lokasi S1.

Gambar 5 memperlihatkan kurva dispersi untuk lokasi S4 di Rancakasumba, dengan nilai frekuensi berkisar antara $4 \mathrm{~Hz}$ hingga $28 \mathrm{~Hz}$. Kurva dispersi dihasilkan dengan iterasi sebanyak 30 kali dengan nilai RMSE sebesar 1,19\%. Berdasarkan kurva dispersi ini, kecepatan fase menurut data observasi berkisar antara 110,87 $\mathrm{m} /$ detik hingga 177,3 $\mathrm{m} /$ detik, sedangkan kecepatan fase berdasarkan data prediksi berkisar antara $110,29 \mathrm{~m} /$ detik hingga $177,39 \mathrm{~m} /$ detik. 
Kenaikan $V s$ terhadap kedalaman juga diperlihatkan pada lokasi S4 (Gambar 5), dimulai dari nilai $121,41 \mathrm{~m} /$ detik hingga mencapai nilai $191,67 \mathrm{~m} /$ detik pada kedalaman $30 \mathrm{~m}$. Nilai $V s$ di lokasi ini sedikit lebih tinggi dibandingkan nilai $V s$ di lokasi S3 untuk daerah yang sama.

Gambar 6 memperlihatkan kurva dispersi untuk lokasi S5 di Desa Sumbersari, dengan nilai RMSE sebesar $0,734 \%$ dengan iterasi sebanyak 20 kali. Nilai frekuensi berkisar antara $4 \mathrm{~Hz}$ hingga $28 \mathrm{~Hz}$ dan kecepatan fase data observasi berkisar antara $124,65 \mathrm{~m} /$ detik hingga 201,08 $\mathrm{m} /$ detik dan berdasarkan data prediksi berkisar antara 124,19 $\mathrm{m} /$ detik hingga 200,05 m/detik. Gambar 6 juga menunjukkan peningkatan kecepatan gelombang geser $(V s)$ terhadap kedalaman hasil dari proses inversi dari model awal $V s$, di mana kenaikan nilai
Vs dimulai dari nilai $125,82 \mathrm{~m} /$ detik hingga mencapai nilai $232,96 \mathrm{~m} /$ detik pada kedalaman 30 $\mathrm{m}$. Dengan demikian, lapisan tanah di lokasi S5 ini memiliki nilai $V s$ hingga kedalaman $30 \mathrm{~m}$ paling tinggi.

\section{Analisis nilai Vs30}

Tabel 2 menyajikan hasil analisis nilai rata-rata Vs30 untuk penentuan kelas tapak menurut SNI 1726:2012 (BSN, 2012). Berdasarkan nilai Vs30, lokasi S1 (Bojongemas), S2 (Rancakasumba), dan S3 (Rancakasumba), lapisan tanah hingga kedalaman $30 \mathrm{~m}$ termasuk dalam kelas tapak E, yang mengindikasikan jenis tanah lunak. Sedangkan di lokasi S2 (Rancaekek Kencana) dan S5 (Sumbersari), lapisan tanah berada pada kelas tapak D, yang menunjukkan jenis tanah medium.

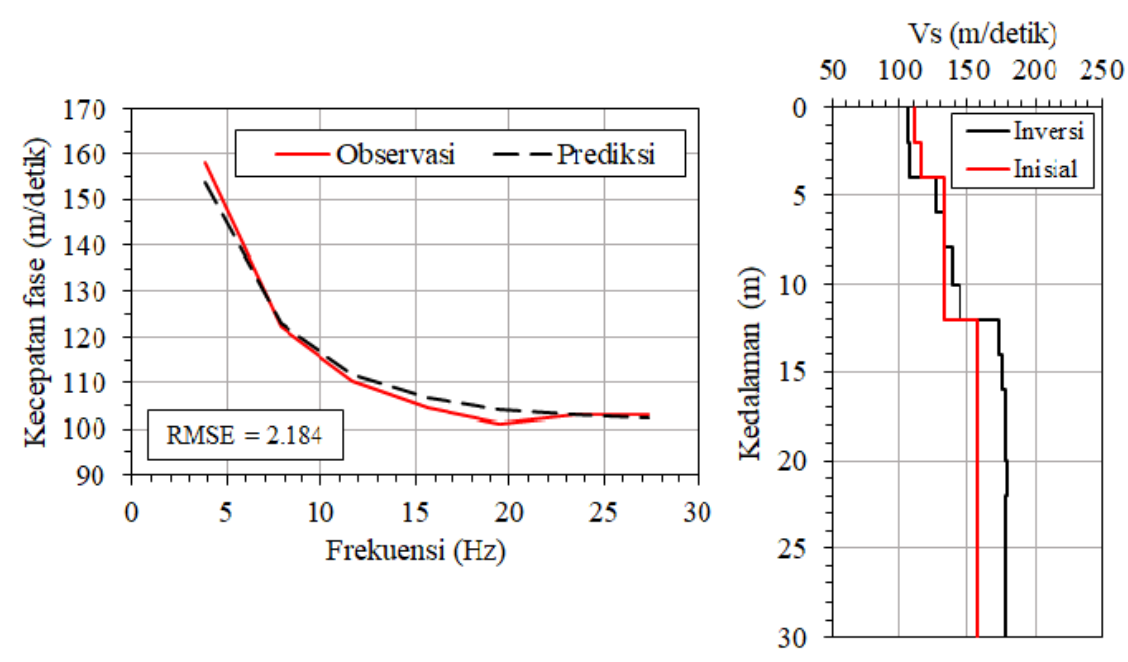

Gambar 2. Kurva dispersi dan profil Vs untuk lokasi S1 di Desa Bojongemas.
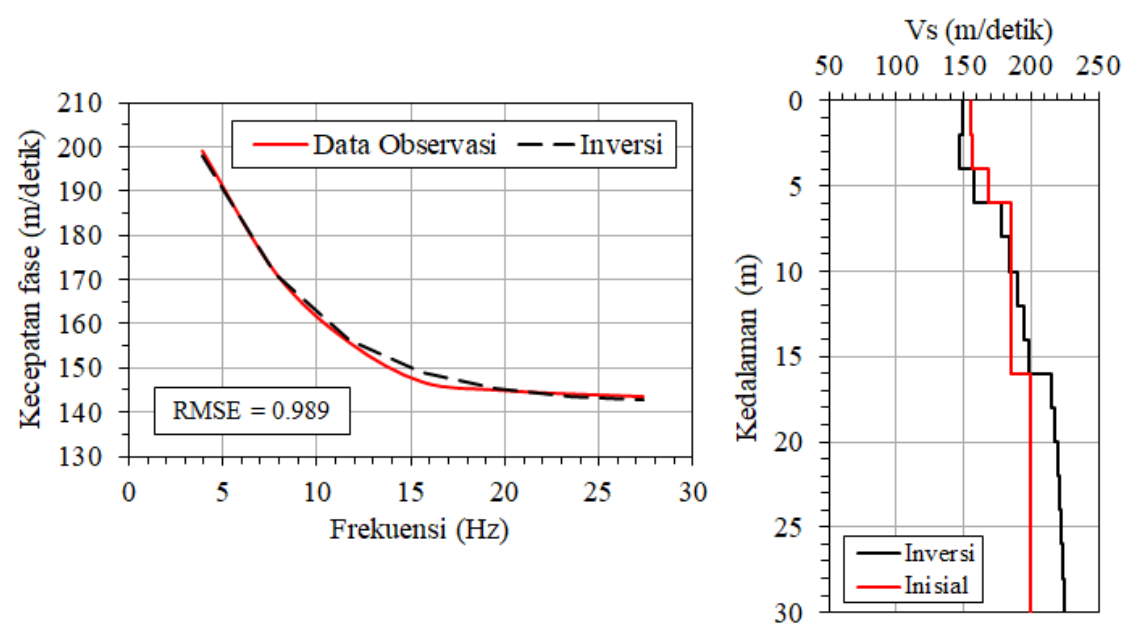

Gambar 3. Kurva dispersi dan profil Vs untuk lokasi S2 di Kelurahan Rancaekek Kencana. 


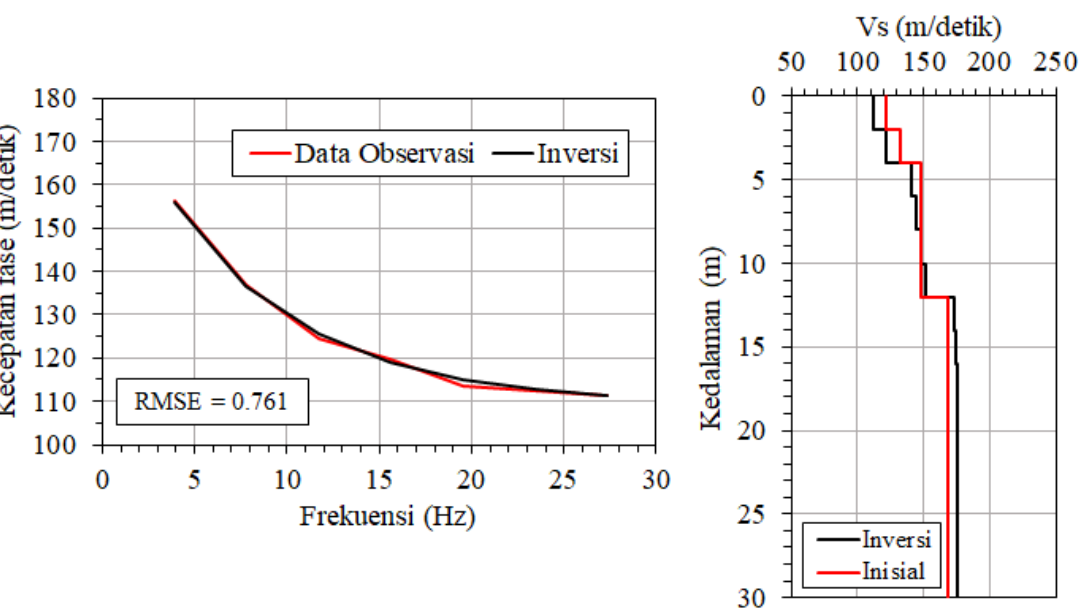

Gambar 4. Kurva dispersi dan profil Vs untuk lokasi S3 di Desa Rancakasumba.

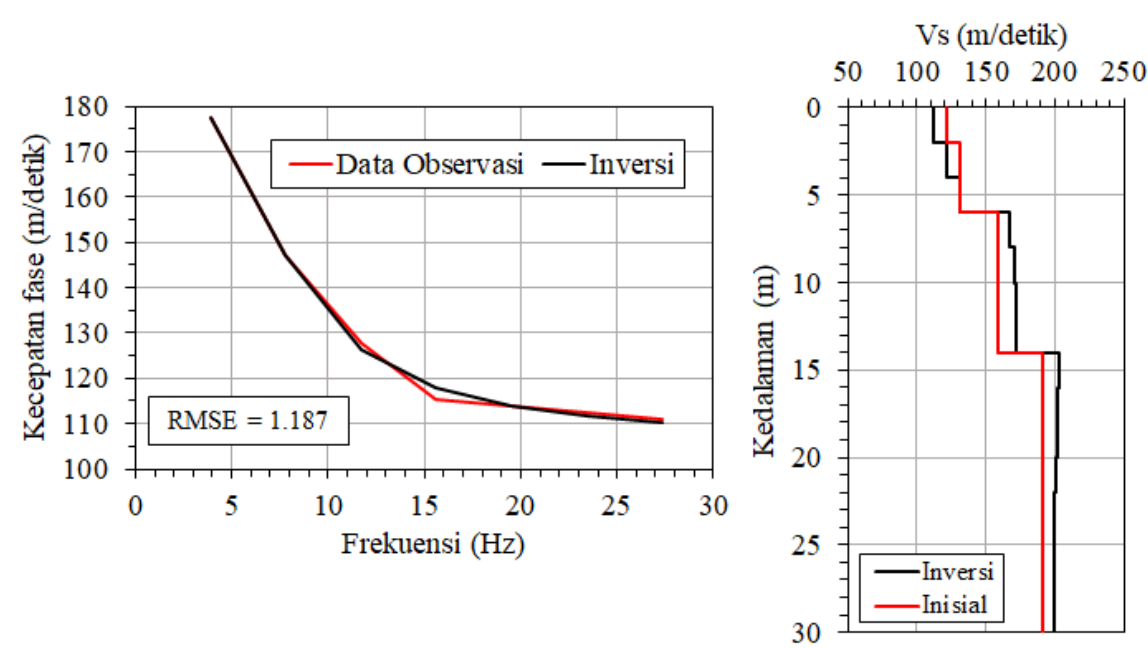

Gambar 5. Kurva dispersi dan profil Vs untuk lokasi S4 di Desa Rancakasumba.

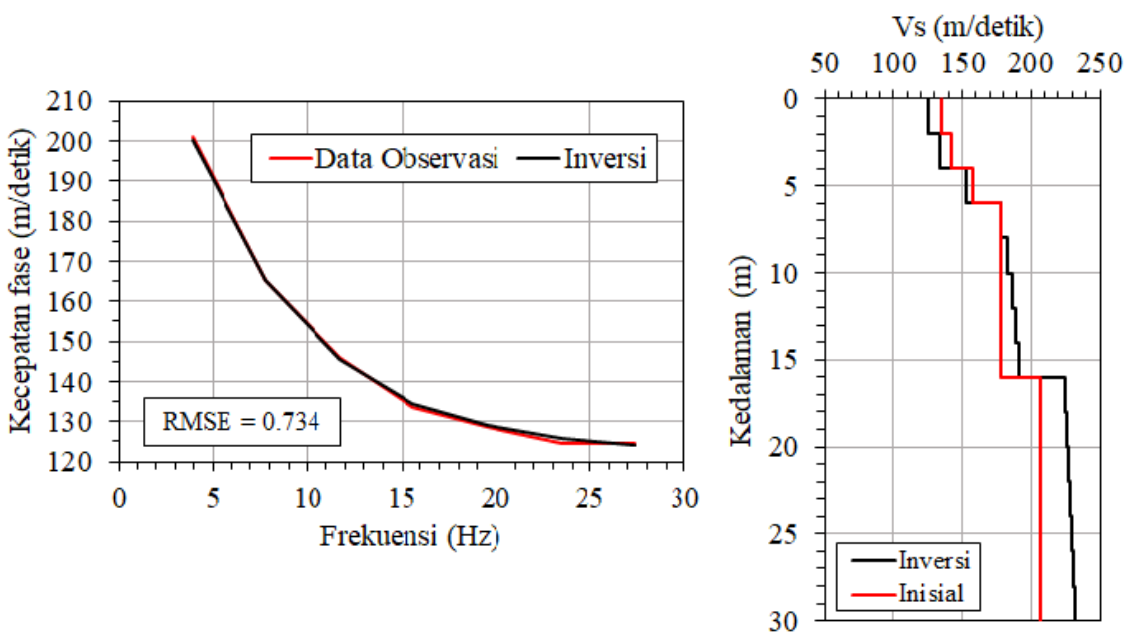

Gambar 6. Kurva dispersi dan profil Vs untuk lokasi S5 di Desa Sumbersari. 
Dengan demikian, jenis kelas tapak lapisan tanah di wilayah Cekungan Bandung sangat bervariasi sehingga akan mempengaruhi nilai percepatan puncak di permukaan tanah dan juga potensi likuifaksi di setiap lokasi.

\section{Percepatan tanah puncak (PGA)}

Tabel 3 menyajikan hasil perhitungan percepatan tanah puncak batuan dasar $(P G A)$ untuk sumber gempa bumi Sesar Lembang (Mw 6,5) dengan menggunakan persamaan Boore et al. (1997), dan percepatan tanah puncak permukaan $\left(P G A_{M}\right)$ yang dihitung menggunakan interpolasi linier koefisien situs menurut SNI 1726:2012 (BSN, 2012). Berdasarkan Tabel 3, nilai $P G A$ di lokasi penelitian berkisar antara 0,16 dan $0,18 \mathrm{~g}$. Sementara itu, peta bahaya gempa deterministik tahun 2017 untuk 150\% median memberikan nilai $P G A$ dalam rentang antara 0,2 dan $0,3 \mathrm{~g}$ (Kementerian PUPR, 2017) karena menggunakan magnitudo Sesar Lembang $\mathrm{Mw}$ 6,8 dan berdasarkan fungsi atenuasi yang terbaru seperti Boore dan Atkinson (2008), Campbell dan Bozorgnia (2008), dan Chiou dan Youngs (2008) Perbedaan nilai magnitudo gempa dan rumus fungsi atenuasi yang digunakan dalam analisis menjadi faktor utama penyebab perbedaan nilai $P G A$ ini dengan hasil perhitungan dalam penelitian ini. Tabel 3 juga memperlihatkan nilai $P G A_{M}$ yang berada pada rentang antara 0,25 dan $0,34 \mathrm{~g}$, di mana nilai $P G A_{M}$ tertinggi berada di daerah Bojongemas, dan nilai terendah di daerah Rancaekek Kencana.

\section{Analisis potensi likuifaksi}

Tabel 4 menyajikan hubungan kedalaman muka air tanah dan potensi likuifaksi (Youd et al., 1979). Berdasarkan kedalaman muka air tanah, daerah Bojongemas memiliki potensi likuifaksi yang tinggi, daerah Rancaekek Kencana memiliki potensi likuifaksi yang rendah dan untuk daerah Rancakasumba dan Sumbersari memiliki potensi likuifaksi yang sangat tinggi hingga tinggi. Dengan demikian, potensi likuifaksi di wilayah Cekungan Bandung bervariasi dan dipengaruhi oleh kedalaman muka airtanah di setiap daerah. Namun, selain dari kedalaman muka air tanahnya, ada beberapa faktor lain yang menentukan potensi likuifaksi, yaitu jenis tanah dan kepadatan tanah. Potensi likuifaksi akan menurun jika terdapat lapisan lempung di lokasi yang diteliti.
Gambar 7 hingga Gambar 11 menyajikan hasil analisis potensi likuifaksi di setiap lokasi berdasarkan data $V s$ untuk setiap lapisan tanah dalam bentuk grafik $C S R$, dan $C R R_{M}$ terhadap kedalaman. Jenis lapisan tanah diperoleh dari uji distribusi ukuran partikel dari conto tanah hasil pemboran di setiap lokasi (Febriana et al., 2020). Hasil analisis menunjukkan bahwa lapisan pasir di semua lokasi berpotensi likuifaksi pada kedalaman yang bervariasi karena dipengaruhi oleh kedalaman muka airtanah, ketebalan lapisan pasir dan perbedaan percepatan tanah puncak yang dapat dihasilkan oleh gempabumi Sesar Lembang (Mw 6,5).

Pada lokasi S1, potensi likuifaksi akan terjadi pada lapisan pasir yang terletak di kedalaman antara 6 dan $10 \mathrm{~m}$ serta kedalaman $28 \mathrm{~m}$ (Gambar 7). Berdasarkan Gambar 8, pada lokasi S2 (Rancaekek Kesumba), lapisan pasir pada kedalaman antar 4 dan $6 \mathrm{~m}$ akan mengalami likuifaksi. Sementara itu, pada lokasi S3 (Rancakasumba), likuefaksi akan terjadi pada kedalaman 16 m dan 26 m (Gambar 9). Sedangkan pada lokasi S4 (Rancakasumba), lapisan pasir pada kedalaman antara 4 dan $6 \mathrm{~m}$ serta $30 \mathrm{~m}$ berpotensi likuifaksi (Gambar 10). Lapisan pasir pada kedalaman antara 14 dan 16 m di lokasi S5 akan mengalami likuifaksi (Gambar 11). Dengan demikian, daerah Bojongemas mempunyai potensi likuifaksi yang lebih tinggi dibandingkan lokasi lainnya. Disamping itu, berdasarkan hasil analisis dengan besaran gempa dan percepatan tanah puncak yang digunakan dalam penelitian ini, likuifaksi hanya terjadi pada lapisan pasir dengan nilai $V s$ kurang dari $200 \mathrm{~m} /$ detik di semua lokasi penelitian. Akan tetapi, lapisan pasir dengan $V s>200 \mathrm{~m} /$ detik dapat mengalami likuifaksi jika nilai $P G A$ lebih besar dari $0,18 \mathrm{~g}$.

Tabel 5 menyajikan perbandingan hasil analisis potensi likuifaksi ini dengan hasil penelitian Febriana et al. (2020). Terdapat kesamaan kedalaman lapisan pasir yang terlikuifaksi dengan hasil analisis likuifaksi berdasarkan metode uji penetrasi standard (lihat Table 5). Walaupun metode $M A S W$ memberikan kemudahaan dalam pengambilan data $V s$, akan tetapi metode ini memerlukan data persentase kandungan butiran halus dalam perhitungan $C R R$. Dengan demikian, penggunaan metode $V s$ perlu didukung pemboran teknik untuk mendapatkan informasi kandungan partikel halus setiap jenis lapisan tanah. 
Tabel 2. Kelas tapak lokasi penelitian berdasarkan nilai Vs30.

\begin{tabular}{clcll}
\hline $\begin{array}{c}\text { Kode } \\
\text { lokasi }\end{array}$ & \multicolumn{1}{c}{ Lokasi } & $\begin{array}{c}\text { Vs30 } \\
(\mathbf{m} / \mathbf{d e t i k})\end{array}$ & Kelas tapak (site class) \\
\hline S1 & Bojongemas, Kec. Solokan Jeruk & 151,61 & E & Lunak (Soft soil) \\
S2 & Rancaekek Kencana, Kec. Rancaekek & 192,23 & D & Medium (Stiff soil) \\
S3 & Rancakasumba, Kec. Solokan Jeruk & 156,60 & E & Lunak (Soft soil) \\
S4 & Rancakasumba, Kec. Solokan Jeruk & 170,31 & E & Lunak (Soft soil) \\
S5 & Sumbersari, Kec. Ciparay & 188,32 & D & Medium (Stiff soil) \\
\hline
\end{tabular}

Tabel 3. Nilai percepatan tanah puncak $(P G A)$ di lokasi penelitian

\begin{tabular}{clll}
\hline $\begin{array}{c}\text { Kode } \\
\text { lokasi }\end{array}$ & \multicolumn{1}{c}{ Lokasi } & $\boldsymbol{P G A}(\mathbf{g})$ & $\boldsymbol{P G A}_{\mathbf{M}}(\mathbf{g})$ \\
\hline S1 & Bojongemas, Kec. Solokan Jeruk & 0,18 & 0,34 \\
S2 & Rancaekek Kencana, Kec. Rancaekek & 0,17 & 0,25 \\
S3 & Rancakasumba, Kec. Solokan Jeruk & 0,17 & 0,33 \\
S4 & Rancakasumba, Kec. Solokan Jeruk & 0,16 & 0,32 \\
S5 & Sumbersari, Kec. Ciparay & 0,18 & 0,26 \\
\hline
\end{tabular}

Tabel 4. Hubungan kedalaman muka air tanah dan potensi likuifaksi (Youd et al., 1979)

\begin{tabular}{clcc}
\hline $\begin{array}{c}\text { Kode } \\
\text { lokasi }\end{array}$ & \multicolumn{1}{c}{ Lokasi } & $\begin{array}{c}\text { Kedalaman } \\
\text { muka airtanah (m) }\end{array}$ & $\begin{array}{c}\text { Klasifikasi } \\
\text { potensi likuifaksi }\end{array}$ \\
\hline S1 & Bojongemas, Kec. Solokan Jeruk & 7,0 & Tinggi \\
S2 & Rancaekek Kencana, Kec. Rancaekek & 15,0 & Rendah \\
S3 & Rancakasumba, Kec. Solokan & 3,0 & Sangat tinggi-tinggi \\
S4 & Rancakasumba, Kec. Solokan & 3,0 & Sangat tinggi-tinggi \\
S5 & Sumbersari, Kec. Ciparay & 3,0 & Sangat tinggi-tinggi \\
\hline
\end{tabular}

Tabel 5. Kedalaman lapisan pasir terlikuifaksi di setiap lokasi penelitian.

\begin{tabular}{clcc}
\hline $\begin{array}{c}\text { Kode } \\
\text { lokasi }\end{array}$ & \multicolumn{1}{c}{ Lokasi } & \multicolumn{2}{c}{ Kedalaman lapisan pasir terlikuifaksi (m) } \\
\cline { 3 - 4 } & & Penelitian ini & Febriana et al., (2020) \\
\hline S1 & Bojongemas, Kec. Solokan Jeruk & $6-10$ dan 28 & $6-10$ \\
S2 & Rancaekek Kencana, Kec. Rancaekek & $4-6$ & $0-6$ \\
S3 & Rancakasumba, Kec. Solokan Jeruk & 16 dan 26 & 16 \\
S4 & Rancakasumba, Kec. Solokan Jeruk & $4-6$ dan 30 & $4-6$ \\
S5 & Sumbersari, Kec. Ciparay & $14-16$ & $14-16$ \\
\hline
\end{tabular}




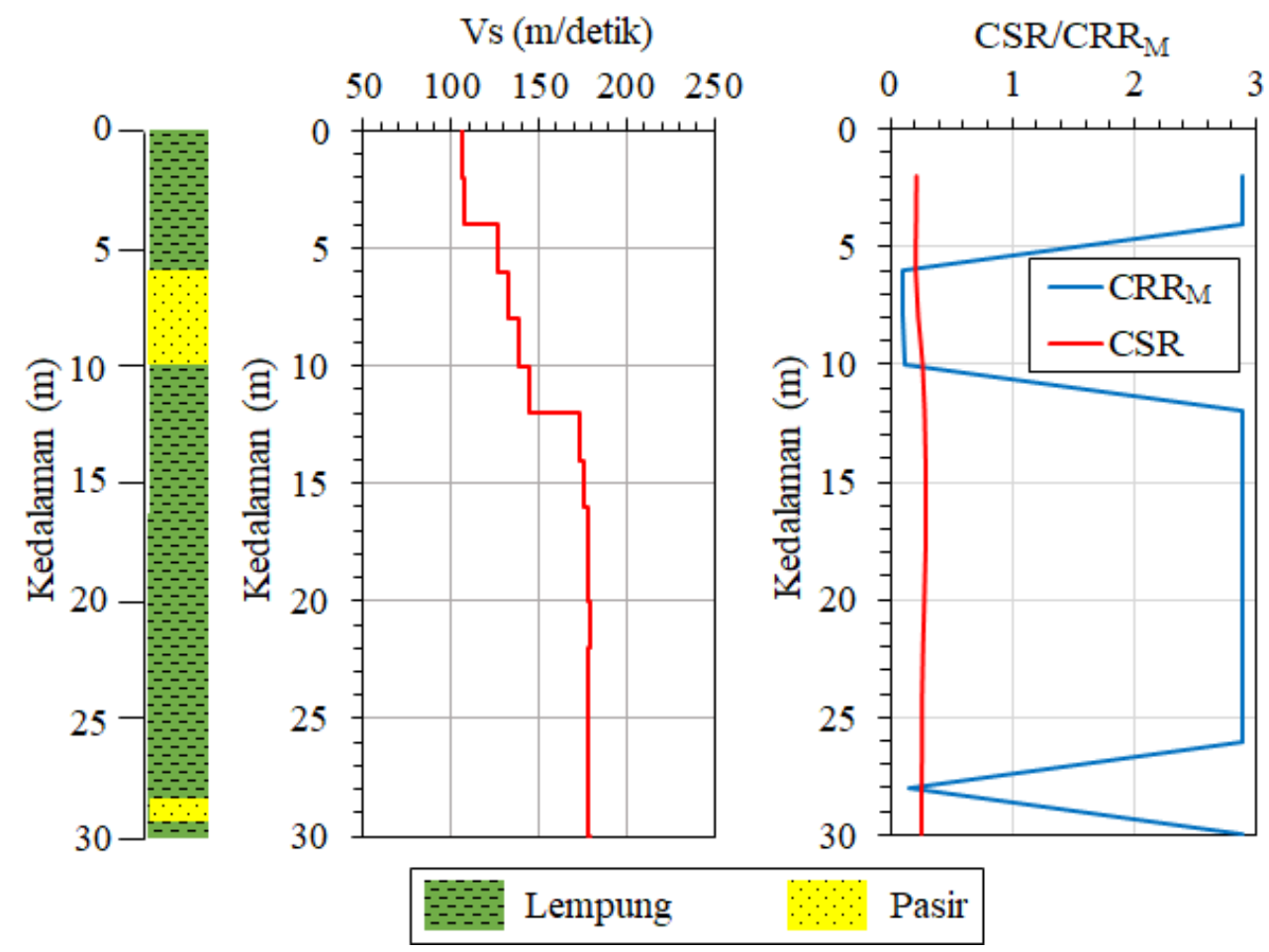

Gambar 7. Grafik jenis lapisan tanah, profil $V s, C S R$ dan $C R R_{M}$ terhadap kedalaman di lokasi S1 (Bojongemas).

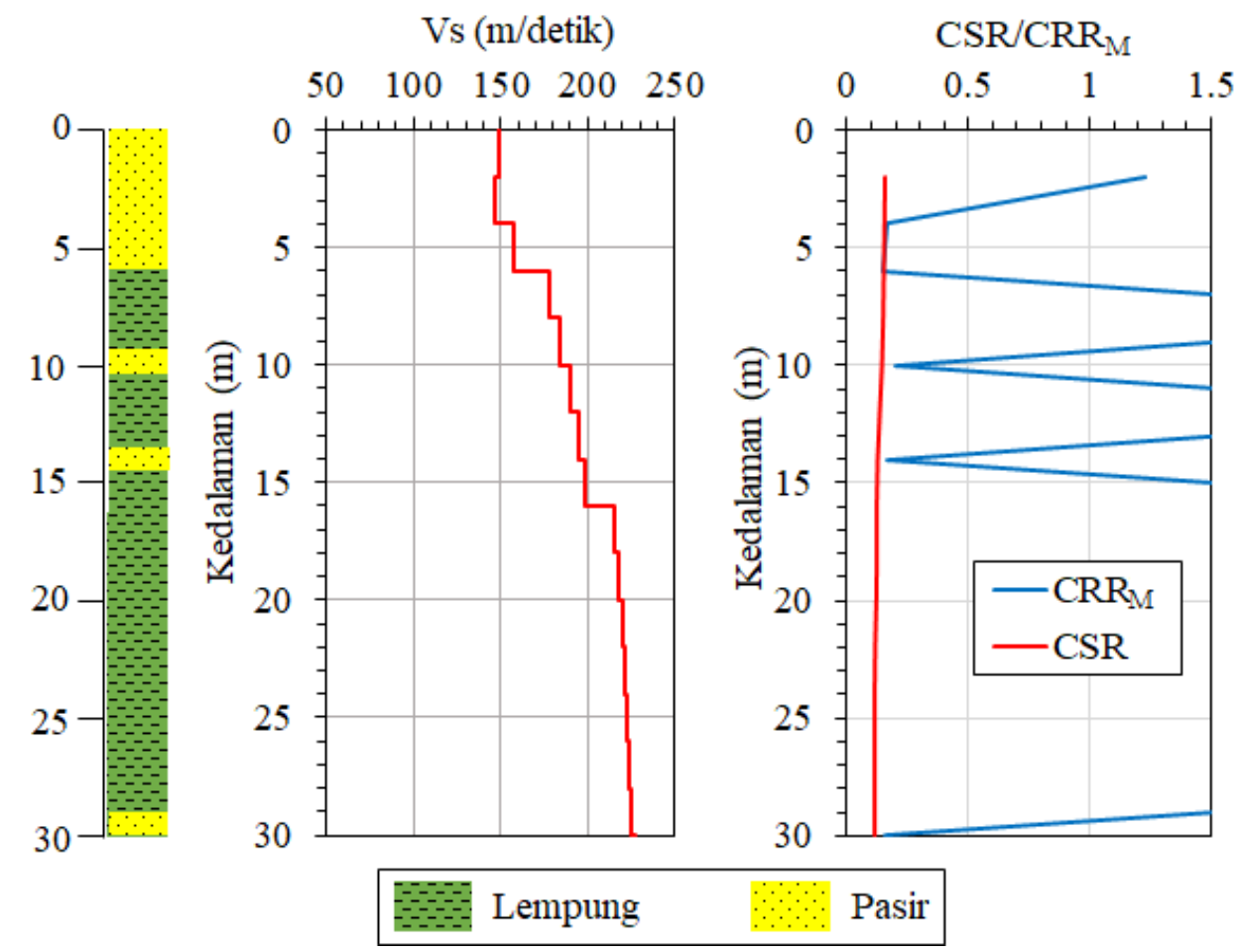

Gambar 8. Grafik jenis lapisan tanah, profil $V s, C S R$ dan $C R R_{M}$ terhadap kedalaman di lokasi S2 (Rancaekek Kencana). 


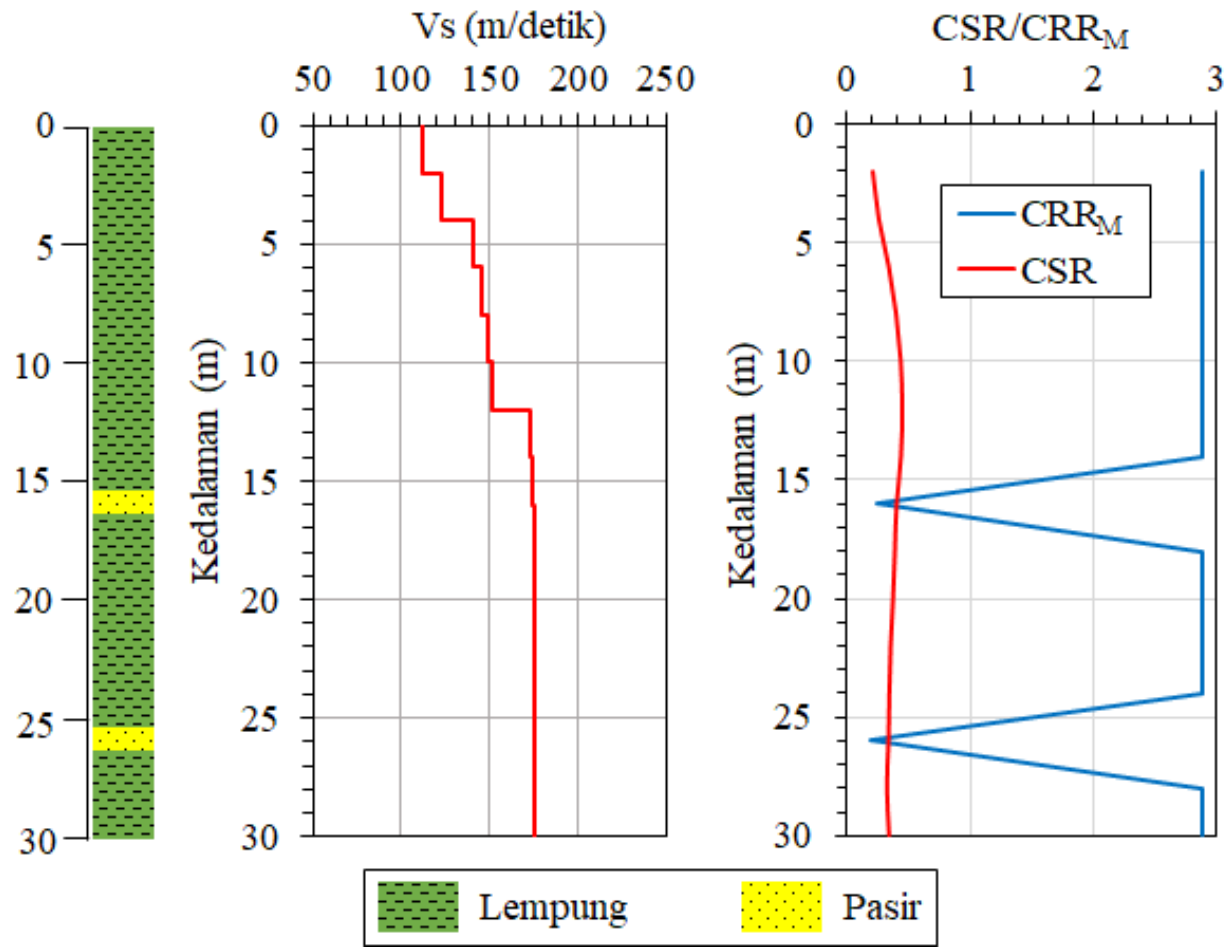

Gambar 9. Grafik jenis lapisan tanah, profil $V s, C S R$ dan $C R R_{M}$ terhadap kedalaman di lokasi S3 (Rancakasumba).

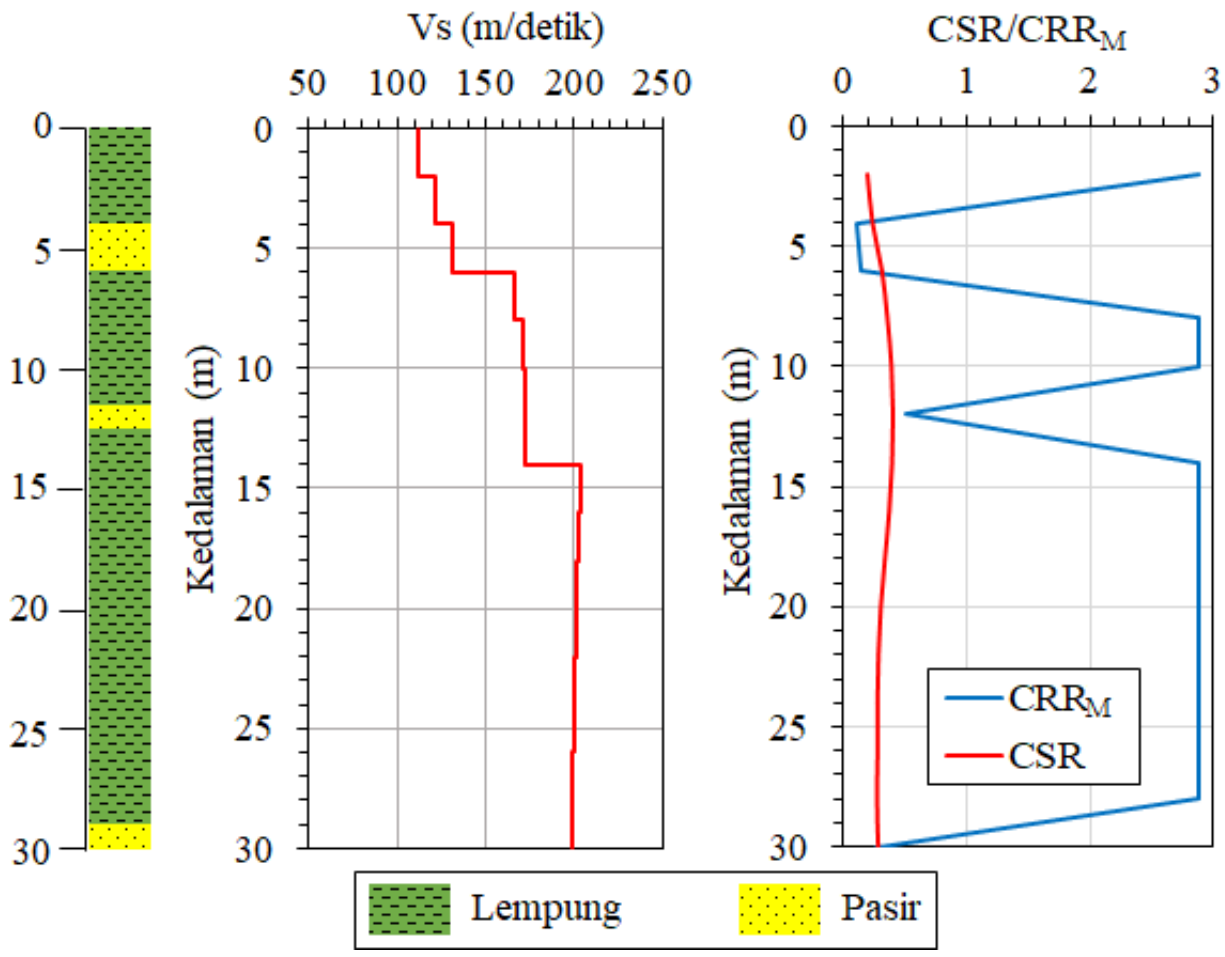

Gambar 10. Grafik jenis lapisan tanah, profil $V s, C S R$ dan $C R R_{M}$ terhadap kedalaman di lokasi S4 (Rancakasumba). 


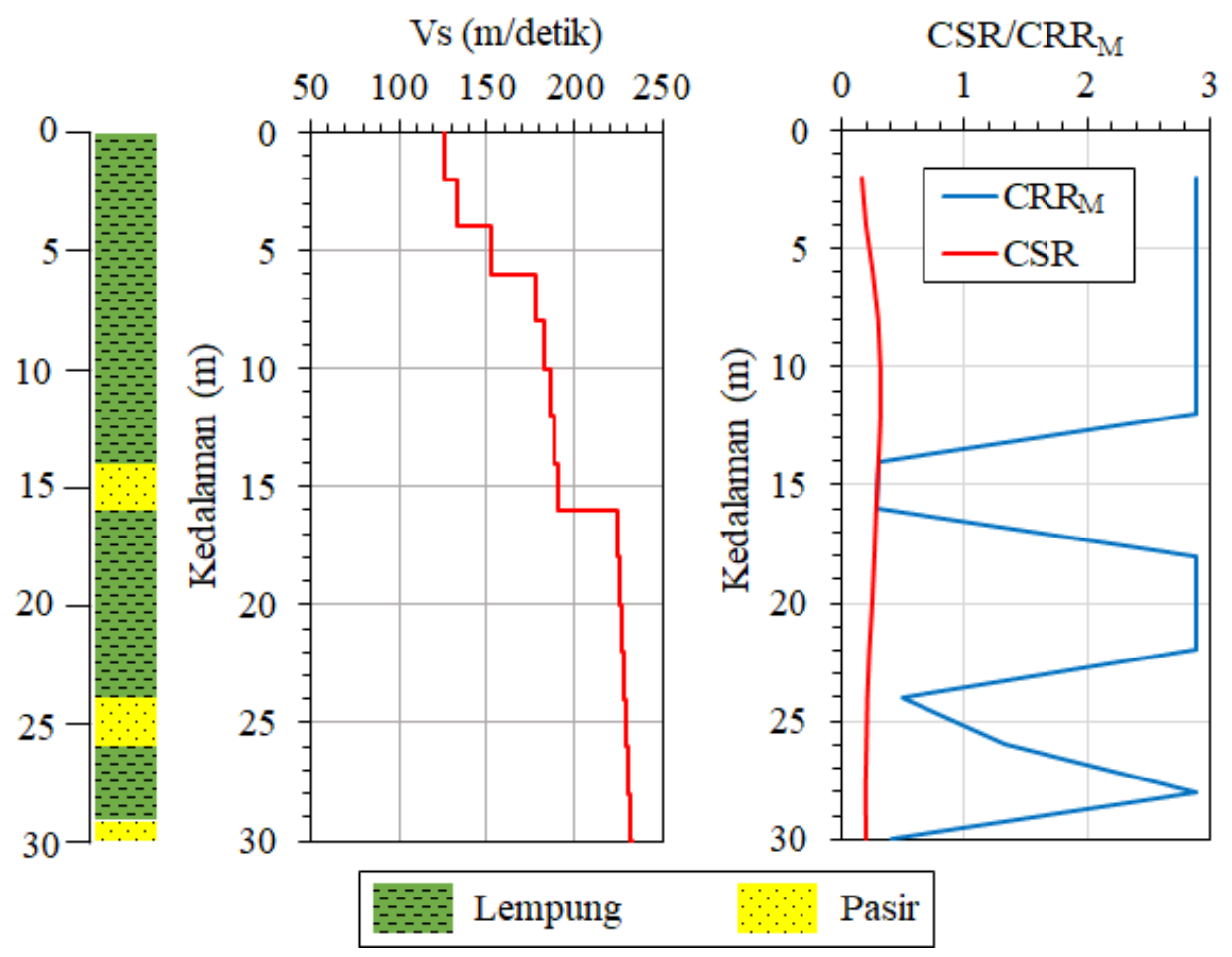

Gambar 11. Grafik jenis lapisan tanah, profil $V s, C S R$ dan $C R R_{M}$ terhadap kedalaman di lokasi S5 (Sumbersari).

Dengan mempertimbangkan gempa bumi Sesar Lembang (Mw 6,5), potensi likuifaksi di wilayah Cekungan Bandung sangat bervariasi karena adanya kontrol kondisi geologi dan hidrologi bawah permukaan. Oleh karena itu, pengukuran $M A S W$ perlu dilakukan selain juga investigasi jenis lapisan tanah di seluruh wilayah Cekungan Bandung, hal ini ditujukan untuk menghasilkan informasi yang lebih detil yaitu mikrozonasi potensi likuifaksi yang diperlukan dalam penyusunan rencana tata ruang wilayah Cekungan Bandung berbasis bencana gempa bumi.

\section{KESIMPULAN}

Penelitian potensi likuifaksi dengan menggunakan metode $M A S W$ dilakukan di beberapa lokasi di beberapa daerah di wilayah Cekungan Bandung dengan menggunakan data $V s$ hingga kedalaman $30 \mathrm{~m}$. Hasil analisis $M A S W$ menunjukkan bahwa lapisan tanah di wilayah Cekungan Bandung dapat diklasifikasi dalam kelas situs E dan D. Berdasarkan nilai percepatan tanah puncak akibat gempa bumi Sesar Lembang (Mw 6,5) dan kondisi geologi serta kedalaman air tanah, lapisan pasir di wilayah Cekungan Bandung berpotensi likuifaksi pada kedalaman dan ketebalan yang bervariasi
Mempertimbangkan profil kecepatan gelombang geser $(V s)$, maka daerah Bojongemas berpotensi likuifaksi lebih besar dibandingkan dengan daerah Rancaekek Kencana, Rancakasumba dan Sumbersari karena lapisan pasir dengan nilai $V s<$ $175 \mathrm{~m} /$ detik yang tebal. Hasil penelitian ini menunjukkan kesesuaian dengan hasil analisis likuifaksi berdasarkan metode uji penetrasi standard. Mempertimbangkan variasi lapisan tanah dan kedalaman muka air tanah, maka perlu dilakukan pengukuran $M A S W$ di daerah-daerah lain di wilayah Cekungan Bandung untuk menghasilkan mikrozonasi potensi likuifaksi yang lebih rinci.

\section{KONTRIBUSI PENULIS}

AT merumuskan ide penelitian, mengumpulkan data pengukuran seismik refraksi dan menyempurnakan draft makalah, NAD pengolahan dan analisis data MASW serta menyiapkan draft makalah, dan IM membimbing pengolahan data $M A S W$. Para penulis adalah sebagai kontributor utama dan memberikan kontribusi yang sama dalam penulisan makalah ini. 


\section{UCAPAN TERIMA KASIH}

Penulis mengucapkan terima kasih kepada Pusat Penelitian Geoteknologi LIPI di mana penulis dapat menggunakan laboratorium dan sarana prasarana penelitian lainnya dan juga data hasil pengukuran seismik refraksi. Penulis juga mengucapkan terima kasih kepada Mochammad Rizki Rinaldi, mahasiswa program studi Geofisika, Universitas Padjajaran, yang telah membantu pengukuran seismik refraksi.

\section{DAFTAR PUSTAKA}

Ambarwati, I.W., Feranie, S., Tohari, A., 2020. Analisis potensi likuifaksi di wilayah Cekungan Bandung dengan menggunakan metode uji penetrasi konus. Ris.Geo.Tam Vol. 30, No.1, Juni 2020, 21-37. DOI: 10.14203/risetgeotam2020.v30.1038.

Andrus, R.D., Stokoe, K.H., 1997. Liquefaction resistance based on shear wave velocity. Technical Report NCEER-97- 0022. In: Youd, T. L. and Idriss, I. M. (eds.), NCEER Workshop on Evaluation of Liquefaction Resistance of Soils, Salt Lake City, Utah, 89-128.

Andrus, R.D., Stokoe, K.H., 2000. Liquefaction resistance of soils shear-wave velocity. J. Geotech. Geoenvironmental Eng. 126. https://doi.org/10.1061/(ASCE)1090-0241( 2000)126:11(1015).

Boore, D.M., Joyner, W.B., Fumal, T.E., Survey, U.S.G., Park, M., 1997. Equations for estimating horizontal response spectra and peak acceleration from western North American earthquakes: A summary of recent work 68.

Boore, D., Atkinson, G., 2008. Ground-motion prediction equations for the average horizontal component of PGA, PGV, and 5\%-damped PSA at spectral periods between $0.01 \mathrm{~s}$ and $10.0 \mathrm{~s}$. Earthquake Spectra 24, 99 138.

BSN, 2012. SNI 1726:2012. Tata cara perencanaan ketahanan gempa untuk struktur bangunan gedung dan non gedung. Badan Standarisasi Nasional, 138 hal.

Campbell, K.W., Bozorgnia, Y., 2008. NGA ground motion model for the geometric mean horizontal component of PGA, PGV,
PGD, and 5\% damped linear elastic response spectra for periods ranging from 0.01 to $10 \mathrm{~s}$. Earthquake Spectra 24, 139-171.

Chiou, B., Youngs, R., 2008. An NGA model for the average horizontal component of peak ground motion and response spectra. Earthquake Spectra 24, 173-216.

Dam, M.A.C., Suparan, P., Nossin, J.J., Voskuil R.P.G.A., 1996. A chronology for geomorphological developments in the greater Bandung area, West-Java, Indonesia. Journal of Southeast Asian Earth Sciences, 14(1-2), 101-115.

Daryono, M.R., Natawidjaja, D.H., Sapiie, B., Cummins, P., 2019. Tectonophysics earthquake geology of the Lembang Fault, West Java, Indonesia. Tectonophysics 751, 180-191. https://doi.org/10.1016/j.tecto. 2018.12.014.

Darvasi, Y., Agnon, A., 2019. Calibrating a new attenuation curve for the Dead Sea region using surface wave dispersion surveys in sites damaged by the 1927 Jericho earthquake. Solid Earth, 10, 379-390. https://doi.org/10.5194/se-10-379-2019.

Erken, A., Şengül Nomaler, G., Gündüz, Z., 2018. The development of attenuation relationship for Northwest Anatolia region. Arab J Geosci., 11, 21. https://doi.org/10.1007 /s12517-017-3359-4.

Febriana, R.P., Feranie, S., Tohari, A., 2020. Analisis potensi likuefaksi di daerah Cekungan Bandung berdasarkan data standard penetration test (SPT). Jurnal Lingkungan dan Bencana Geologi Vol. 11 No. 1, April 2020: 25-39.

Giocoli, A., Quadrio, B., Bellanova, J., Lapenna, V., Piscitelli, S., 2014. Electrical resistivity tomography for studying liquefaction induced by the May 2012 Emilia-Romagna earthquake ( $\mathrm{Mw}=6.1$, northern Italy). Nat. Hazards Earth Syst. Sci. 14, 731-737. https://doi.org/10.5194/nhess-14-731-2014.

Grandis, H., 2009. Pengantar pemodelan inversi Geofisika. Himpunan Ahli Geofisika Indonesia (HAGI), Bandung, Indonesia.

Handayani, L., Mulyadi, D., Wardhana, D.D., Nur, W.H., 2009. Percepatan pergerakan 
tanah maksimum daerah Cekungan Bandung: Studi kasus gempa Sesar Lembang. J. Sumber Daya Geol. 19, 333337.

Harnandi, D., Iskandar, N., Nuzulliyantoro, A.T., 2000. Pengelolaan air tanah Cekungan Bandung. Buletin Geologi Tata Lingkungan, $1-6$.

Hayashi, K., 2003. Data acquisition and analysis of active and passive surface wave methods. OYO Corporation.

Hutasoit, L., 2009. Kondisi Permukaan Air Tanah dengan dan tanpa peresapan buatan di daerah Bandung: Hasil simulasi numerik. Jurnal Geologi Indonesia, 4(3), 177-188. https://doi.org/10.1704/ijog.vol4no3.20093.

Idriss, I.M., Boulanger, R.W., 2008. Soil liquefaction during earthquake, Monograph. ed. EERI Publication, Earthquake Engineering Research Institute, Oakland.

Kementerian PUPR, 2017. Peta sumber dan bahaya gempa Indonesia tahun 2017. Disusun oleh Pusat Studi Gempa Nasional, Pusat Litbang Perumahan dan Permukiman, 376 hal.

Lu, Z., Wilson, G.V., 2017. Imaging a soil Fragipan using a high-frequency multichannel analysis of surface wave method. J. Appl. Geophys. https://doi.org/10.1016/ j.jappgeo.2017.05.011.

Olafsdottir, E.A., 2014. Multichannel analysis of surface waves methods for dispersion analysis of surface wave data. University of Iceland, Reykjavik, Iceland.

Pegah, E., Liu, H., 2016. Application of nearsurface seismic refraction tomography and multichannel analysis of surface waves for geotechnical site characterizations: a case study. Eng. Geol. 208, 100-113. https://doi.org/10.1016/j.enggeo.2016.04.02 1.

Robertson, P. K., Woeller, D. J., and Finn, W. D. L., 1992. Seismic Cone Penetration Test for evaluating liquefaction potential under cyclic loading. Can. Geotech. J. 29 (4), 686695.
Sa'adah, U., Purwana, Y.M., Djarwanti, N., 2015. Analisis risiko gempa di Kota Surakarta. Matriks Teknik Sipil, 3(1), 30-35. https://doi.org/10.20961/mateksi.v3i1.

Seed, H.B., Idriss, I.M., 1971. Simplified procedure for evaluating soil liquefaction potential. J. Soil Mech. Found. Div. ASCE, 1249-1273.

Shearer, M., 2009. Introduction to seismology. Cambridge University Press, New York, USA.

Sucuoğlu, H., Akkar, S., 2014. Basic earthquake engineering: from seismology to analysis and design. Springer International Publishing.

Silitonga, P.H., 1973. Peta Geologi Lembar Bandung, Jawa Barat, Skala 1:100.000. Pusat Penelitian dan Pengembangan Geologi, Bandung.

Sudjatmiko, 2003. Peta Geologi Lembar Bandung, Jawa, skala 1:100.000. Direktorat Geologi, Bandung.

Sulaeman, C., Hidayati, S., 2011. Gempa bumi Bandung 22 Juli 2011. J. Lingkungan dan Bencana 2, 185-190.

Sykora, D. W., 1987. Creation of a database of seismic shear wave velocities for correlation analysis. Geotechnical Laboratory Miscellaneous Paper GL-87-26, U.S. Army Engineer Waterways Experiment Station, Vicksburg, MS.

Towhata, I., 2008. Geotechnical earthquake engineering. Springer International Publishing, Tokyo. https://doi.org/10.1007/ 978-3-540-35783-4

Villaverde, R., 2009. Fundamental concepts of earthquake engineering, CRC Press in 2004. CRC Press in 2004, California, USA. https://doi.org/10.1201/9781439883112

Youd, T.L., Tinsley, J.C., Perkins, D.M., J., K.E., Preston, R.F., 1979. Liquefaction potential map of San Fernando Valley, California. Progress on seismic zonation in the San Francisco Bay Region. USGS Circular, 807. 
Dewi et al.: Evaluasi Potensi Likuifaksi di Wilayah Cekungan Bandung 